\title{
Reverse micelles in organic solvents: a medium for the biotechnological use of extreme halophilic enzymes at low salt concentration
}

\author{
FRUTOS C. MARHUENDA-EGEA, ${ }^{1,2}$ SONSOLES PIERA-VELÁZQUEZ, ${ }^{1,3}$ CHIQUINQUIRÁ \\ CADENAS $^{1}$ and EDUARDO CADENAS ${ }^{1}$ \\ ${ }^{1}$ División de Bioquímica, Facultad de Ciencias, Universidad de Alicante, Apartado 99, 03080 Alicante, Spain \\ 2 Author to whom correspondence should be addressed (frutos@ua.es) \\ 3 Thomas Jefferson University, BLSB 511, 233 South 10th Street, Philadelphia PA 19107, USA
}

Received December 19, 2001; accepted March 8, 2002; published online April 10, 2002

\begin{abstract}
Summary Alkaline $p$-nitrophenylphosphate phosphatase ( $p$ NPPase) from the halophilic archaeobacterium Halobacterium salinarum (previously halobium) was solubilized at low salt concentration in reverse micelles of hexadecyltrimethylammoniumbromide in cyclohexane with 1-butanol as cosurfactant. The enzyme maintained its catalytic properties under these conditions. The thermodynamic "solvation-stabilization hypothesis" has been used to explain the bell-shaped dependence of $p$ NPPase activity on the water content of reverse micelles, in terms of protein-solvent interactions. According to this model, the stability of the folded protein depends on a network of hydrated ions associated with acidic residues at the protein surface. At low salt concentration and low water content (the ratio of water concentration to surfactant concentration; $w_{0}$ ), the network of hydrated ions within the reverse micelles may involve the cationic heads of the surfactant. The bell-shaped profile of the relationship between enzyme activity and $w_{0}$ varied depending on the concentrations of $\mathrm{NaCl}$ and $\mathrm{Mn}^{2+}$.
\end{abstract}

Keywords: alkaline phosphatase, archaea, CTAB, Halobacterium.

\section{Introduction}

Extreme halophilic organisms may have intracellular salt concentrations as high as $4 \mathrm{M}$, and proteins from these organisms require environments with high ionic strength to maintain their active conformations (Lanyi 1974). These proteins are characterized by an excess of negatively charged amino acids on their surface that interact with ions in the surrounding medium (Zaccai and Eisenberg 1990, Madern et al. 2000). Alkaline $p$-nitrophenylphosphate phosphatase ( $p$ NPPase) from the halophilic archaeobacterium Halobacterium salinarum exhibits behavior typical of extreme halophilic proteins in aqueous medium (Bonet et al. 1991), and requires high salt concentrations (greater than $0.6 \mathrm{M} \mathrm{KCl}$ or $1.2 \mathrm{M} \mathrm{NaCl}$ ) to attain maximum activity. In the absence of salt, the residual activity is only about $15 \%$ of the maximum (Bonet et al. 1991). However,
$p$-NPPase encapsulated in reverse micelles of the cationic surfactant hexadecyltrimethylammonium bromide (CTAB) with $0.85 \mathrm{M} \mathrm{NaCl}$ (Marhuenda-Egea et al. 2000a) maintained its catalytic properties and was found to be more stable in the reverse micellar system than in aqueous medium (MarhuendaEgea et al. 2001a).

The phenomenon of enzyme catalysis in non-polar organic media, within reverse micelles, is currently the focus of intense research (Luisi et al. 1988, Dordick et al. 1998, Tuena de Gómez-Puyou and Gómez-Puyou 1998, Carvalho and Cabral 2000). Reverse micelles consist of three components: amphiphilic surfactant molecules, water and a non-polar organic solvent. The polar heads of the surfactant molecules are directed toward the interior of a water-containing sphere, whereas the aliphatic tails are oriented toward the non-polar organic phase. The water structure within the reverse micelles may resemble that of water adjacent to biological membranes (Boicelli et al. 1982), and it has been suggested that the reverse micellar system reliably mimics the microenvironment that enzymes encounter in the intracellular milieu (Nicot et al. 1985, Luisi et al. 1988, O'Connor and Wiggins 1988, Faeder and Ladanyi 2000).

One of the most important factors determining enzyme behavior in reverse micelles is the water/surfactant molar ratio $\left(w_{0}=\left[\mathrm{H}_{2} \mathrm{O}\right] /[\right.$ surfactant $\left.]\right)$, because there is a direct relationship between $w_{0}$ and the size of the reverse micelles (Martinek et al. 1986). Kabanov et al. (1988) proposed a kinetic model based on the optimum size of the micelles. The structure of water molecules within the micelle is determined by micellar size; if $w_{0}$ increases, the amount of "free" water (water molecules not bound to the surfactant polar heads), relative to the amount of "bound" water, also increases (Luisi et al. 1988). Therefore, micellar size may affect the local aqueous environment, which in turn may affect the catalytic properties of the enzyme in that environment (Bru et al. 1989). Other studies suggest that water has a uniform structure within the interior of the reverse micelle (Novaki and El Seoud 1998). Evidently, the uncertainty about the structure of water within reverse micelles hinders the interpretation of results (Faeder and Ladanyi 2000). 
The influence of protein concentration on the catalytic properties of an enzyme within reverse micelles has not been studied as extensively as that of other parameters, such as $w_{0}, \mathrm{pH}$ and surfactant concentration. However, the importance of this parameter on enzyme activity in reverse micelles was demonstrated by Han et al. (1990): as the enzyme concentration increased, the bell-shaped profile of the relationship between enzyme activity and $w_{0}$ flattened out and the optimum $w_{0}$ value increased. Han et al. (1990) also found that the initial velocity of the reaction increased proportionally with enzyme concentration for all $w_{0}$ values studied. However, the relationship between enzyme activity and enzyme concentration varied depending on $w_{0}$, being linear at low $w_{0}$ values and nonlinear at high $w_{0}$ values (Han et al. 1990).

The main objective of this work was to study the influence of the reverse micellar system on the catalytic activity of $p$ NPPase from $H$. salinarum at low salt concentrations. The behavior of this extremely halophilic enzyme has been investigated because of the potential biotechnological application of halophilic enzymes in reverse micelles as catalysts in organic solvents (Dordick et al. 1998). In such a case, reverse micelles can be considered micro-reactors whose physical properties can be readily altered. The physical properties of this milieu can be continuously modulated and possibly tailored to the characteristics of the reaction taking place in the water pool.

\section{Materials and methods}

\section{Chemicals}

$p$-Nitrophenylphosphate ( $p$ NPP) (disodium salt) was supplied by Boehringer-Mannheim (Germany). All salts were analytical grade chlorides. Hexadecyltrimethylammonium bromide (CTAB) was obtained from Fluka (Switzerland), and organic solvents (cyclohexane and 1-butanol) were purchased from Merck (Germany).

\section{Purification and catalytic activity of pNPPase from Halobacterium salinarum}

p-Nitrophenylphosphate phosphatase from $H$. salinarum (a colorless mutant, NRC 36014) was purified 440-fold according to the method of Bonet et al. (1991). The molecular size of the protein was $24 \mathrm{kDa}$ (Bonet et al. 1991) and the isoelectric point was about 4 . The purified $p$ NPPase was dialyzed for $24 \mathrm{~h}$ at $4{ }^{\circ} \mathrm{C}$ against 200 volumes of $100 \mathrm{mM}$ Tris- $\mathrm{HCl}$ buffer, $\mathrm{pH}$ 8.5 , containing $4 \mathrm{M} \mathrm{NaCl}, 20 \mathrm{mM}$ 2-mercaptoethanol and $5 \mathrm{mM} \mathrm{MnCl}_{2}$, and its concentration determined by the Bradford method (Bradford 1976). Activity of $p$ NPPase was assayed according to Bonet et al. (1991). One unit of activity (U) was defined as the formation of $1 \mathrm{nmol}$ of $p$-nitrophenol $(p \mathrm{NP})$ from $p$ NPP per minute per gram of protein under standard assay conditions. The molar absorption coefficient $(\varepsilon)$ of $p \mathrm{NP}$ at $400 \mathrm{~nm}$ was taken to be $18,300 \mathrm{M}^{-1} \mathrm{~cm}^{-1}$.

\section{Preparation of reverse micelles containing pNPPase}

Purified $p$ NPPase from $H$. salinarum was concentrated by centrifugation at $3000 \mathrm{~g}$ using Centricon 10 ultrafiltration mem- branes (Amicon, Danvers, MA) with a molecular weight cutoff of $10 \mathrm{kDa}$. Reverse micelles were prepared by the injection method (i.e., aqueous solution was added to a solution of surfactant in organic solvent; see Luisi et al. 1988). Controlled amounts of buffer without $\mathrm{NaCl}$ (buffer A: $100 \mathrm{mM}$ Tris- $\mathrm{HCl}$, pH 8.5, $20 \mathrm{mM}$ 2-mercaptoethanol, $5 \mathrm{mM} \mathrm{MnCl}_{2}$ ) and buffered enzyme solution (enzyme in buffer A with $4 \mathrm{M} \mathrm{NaCl}$ ) were added to a mixture of $1 \mathrm{M} 1$-butanol and 0.2 $\mathrm{M} \mathrm{CTAB}$ in cyclohexane. For a $w_{0}$ value of $9.72,9 \mu \mathrm{l}$ of buffered enzyme solution and $341 \mu \mathrm{l}$ of buffer A were added to $10 \mathrm{ml}$ of cyclohexane/1-butanol/CTAB, and the mixture was stirred until completely transparent. Reverse micellar systems with different $w_{0}$ values or different salt concentrations were generated by altering the volume of buffer A injected into the cyclohexane mixture or the $\mathrm{NaCl}$ concentration in the buffered enzyme solution, respectively. At $w_{0}=9.72$, the final concentration of $\mathrm{NaCl}$ and enzyme in the aqueous core of the reverse micelles was $100 \mathrm{mM}$ and $0.6 \mu \mathrm{g} \mathrm{ml}^{-1}$, respectively. The water concentration was determined with a Mettler DL18 Karl Fischer Titrator (Zurich).

\section{Assays for pNPPase activity in reverse micelles}

Mixing of reverse micelles containing enzyme or substrate The $p$ NPPase reaction was initiated by mixing $1 \mathrm{ml}$ of reverse micelles containing $p$ NPPase from $H$. salinarum with $1 \mathrm{ml}$ of reverse micelles containing different concentrations of $p$ NPP (final concentration in the aqueous core ranged from 5.33 to $106.7 \mathrm{mM}$ ) dissolved in buffer A. The salt concentration in the reverse micelles containing enzyme was the same as that in the reverse micelles containing substrate $(0.048 \mathrm{M}, 0.100 \mathrm{M}$ or $0.85 \mathrm{M} \mathrm{NaCl}$ ). Reverse micelles containing the enzyme and those containing $p$ NPP had the same $w_{0}$ values. To generate reverse micelles containing $p$ NPP with a $w_{0}$ value of $9.72,350 \mu \mathrm{l}$ of $p$ NPP solution was added to $10 \mathrm{ml}$ of $1 \mathrm{M} 1$-butanol and $0.2 \mathrm{M}$ CTAB in cyclohexane. Higher $w_{0}$ values were obtained by increasing the amount of $p$ NPP solution injected into the cyclohexane mixture.

Microinjection of substrate Initiation of the $p$ NPPase reaction by injection of substrate solution into reverse micelles containing enzyme was performed as follows. For reverse micelles with a $w_{0}$ value of $8.3,5.6 \mu \mathrm{l}$ of enzyme solution (enzyme in buffer A with $1 \mathrm{M} \mathrm{NaCl}$ ) and $52.4 \mu$ of buffer A (with or without $1 \mathrm{M} \mathrm{NaCl}$ ) were added to $2.5 \mathrm{ml}$ of $1 \mathrm{M}$ 1-butanol and $0.2 \mathrm{M}$ $\mathrm{CTAB}$ in cyclohexane. The mixture was stirred until complete transparency was achieved, and then $18 \mu \mathrm{l}$ of $716 \mathrm{mM} p \mathrm{NPP}$ in buffer equivalent to that in the aqueous core of the reverse micelles (buffer A with $0.075 \mathrm{M}$ or $1 \mathrm{M} \mathrm{NaCl}$ ) was added. Reformation of the reverse micellar system after injection of substrate was considered complete when absolute transparency was obtained by stirring. The final concentration of $p$ NPP in the aqueous core of reverse micelles with a $w_{0}$ value of 8.3 was $172 \mathrm{mM}$.

Hydrolysis of $p$ NPP was followed at $40{ }^{\circ} \mathrm{C}$ by monitoring the increase in absorbance at $400 \mathrm{~nm}$ with a Shimadzu (Kyoto, Japan) UV-160 spectrophotometer. The molar extinction coefficient $(\varepsilon)$ for $p \mathrm{NP}$ at $40{ }^{\circ} \mathrm{C}$ in CTAB reverse micelles was 
$11.3 \times 10^{3} \mathrm{M}^{-1} \mathrm{~cm}^{-1}$ (Marhuenda-Egea et al. 2000a). All kinetic measurements were performed in triplicate.

\section{Determination of enzyme kinetic parameters}

The reaction kinetics were examined by fitting data to the Michaelis-Menten equation: $v=V_{\max }[\mathrm{S}] /\left(K_{\mathrm{m}}+[\mathrm{S}]\right)$. The values of $V_{\max }$ and $K_{\mathrm{m}}$ were determined by nonlinear regression analysis of the corresponding Michaelis-Menten curves ( $v$ versus $[p \mathrm{NPP}])$ by the algorithm of Marquardt-Levenberg with SigmaPlot (Version 1.02, Jandel Scientific, San Rafael, CA). The [S], $V_{\max }$ and $K_{\mathrm{m}}$ values were determined in the aqueous solution volume of the system because the hydrolysis of $p$ NPP took place in this phase (Bru et al. 1995).

\section{Results}

Activity of pNPPase in reverse micelles: effect of salt concentration

The kinetics of $p$ NPPase activity in reverse micelles were determined at both high $(0.85 \mathrm{M})$ and low $(0.048 \mathrm{M}) \mathrm{NaCl}$ concentrations. The results are shown in Figure 1. The kinetic parameters of the purified $p$ NPPase in aqueous medium were: $V_{\max }=27.7 \pm 0.2 \mathrm{U}$ and $K_{\mathrm{m}}=0.43 \pm 0.02 \mathrm{mM}$. When reverse micelles containing enzyme were mixed with reverse micelles containing substrate, the kinetic parameters at 0.85 and $0.048 \mathrm{M} \mathrm{NaCl}$ were similar: $V_{\max }=19.4 \pm 0.4 \mathrm{U}$ and $K_{\mathrm{m}}=$ $31.2 \pm 2.3 \mathrm{mM}$ at $0.85 \mathrm{M} \mathrm{NaCl}$, and $V_{\max }=17.5 \pm 1.0 \mathrm{U}$ and $K_{\mathrm{m}}=38.9 \pm 6.4 \mathrm{mM}$ at $0.048 \mathrm{M} \mathrm{NaCl}$. The hydrolysis of $p$ NPP in reverse micelles appeared to follow Michaelis-Menten kinetics (Figure 1).

\section{Influence of $w_{0}$ on pNPPase activity}

The activity of $p$ NPPase was assessed at various reverse micellar water contents (i.e., $w_{0}$ values). Figure 2 shows the dependence of enzyme activity on $w_{0}$ at 1 and $0.075 \mathrm{M} \mathrm{NaCl}$. The reaction conditions were as described in Materials and methods (microinjection of substrate), but in this particular experiment the substrate concentration in the aqueous core of the micelle was held constant at $150 \mathrm{mM}$. At $1 \mathrm{M} \mathrm{NaCl}$, the optimum $w_{0}$ value was about 9 , whereas the optimum $w_{0}$ value at $0.075 \mathrm{M} \mathrm{NaCl}$ was about 14 . The bell-shaped dependence of activity $(v)$ on $w_{0}$ was much sharper with $1 \mathrm{M} \mathrm{NaCl}$ than with $0.075 \mathrm{M} \mathrm{NaCl}$ (Figure 2).

The influence of $w_{0}$ on $p$ NPPase activity in reverse micelles at low salt concentration $(100 \mathrm{mM} \mathrm{NaCl})$ is shown in Figures 3-5. In Figures 3 and 4, the relationship between $V_{\max }$ and $w_{0}$ exhibited a bell-shaped curve, and the optimum $w_{0}$ value varied depending on the concentration of $\mathrm{Mn}^{2+}$ in the aqueous phase. At $5 \mathrm{mM} \mathrm{MnCl} 2$, the optimum $w_{0}$ value was approximately 15 (Figure 3), whereas at $2 \mathrm{mM} \mathrm{MnCl}_{2}$, the optimum $w_{0}$ value was approximately 13 (Figure 4). In Figures 3 and 4, the overall enzyme concentration ( $\left.[\mathrm{E}]_{\mathrm{ov}}\right)$ was held constant, so that as the water concentration increased, the enzyme concentration within the reverse micelles (i.e., within the water pool; $[\mathrm{E}]_{\mathrm{wp}}$ ) decreased. In Figure 5, [E] $]_{\mathrm{ov}}$ was varied (from 0.056 to $0.088 \mu \mathrm{g} \mathrm{ml}^{-1}$ ) to maintain $[\mathrm{E}]_{\mathrm{wp}}$ at $1.6 \mu \mathrm{g} \mathrm{ml}^{-1}$ at all $w_{0}$ values.

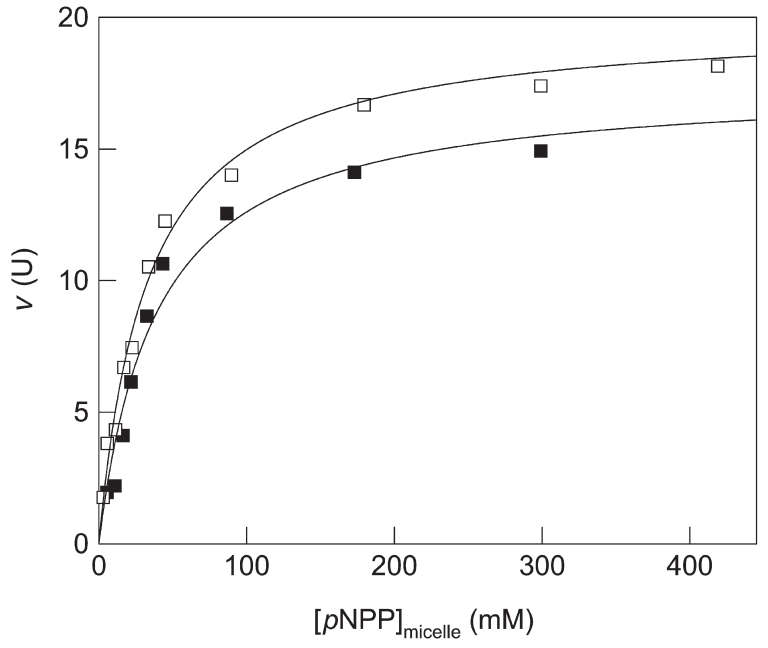

Figure 1. Plots of $p$ NPPase activity in reverse micelles at low salt concentration $(0.048 \mathrm{M} \mathrm{NaCl} ; \square)$ and at high salt concentration $(0.85 \mathrm{M}$ $\mathrm{NaCl}$; $)$. Final conditions: aqueous buffer $100 \mathrm{mM}$ Tris-HCl, $\mathrm{pH} 8.5$ containing $20 \mathrm{mM} 2$-mercaptoethanol and $5 \mathrm{mM} \mathrm{MnCl}_{2}$ with 0.048 or $0.85 \mathrm{M} \mathrm{NaCl} ; w_{0}=10.27$ at $40{ }^{\circ} \mathrm{C}$, with different concentrations of $p$ NPP ranging from 2.5 to $418 \mathrm{mM}$. Protein concentration was $0.6 \mu \mathrm{g}$ $\mathrm{ml}^{-1}$.

When $[\mathrm{E}]_{\mathrm{wp}}$ was held constant at $1.6 \mu \mathrm{g} \mathrm{ml}^{-1}, V_{\max }$ decreased with increasing $w_{0}$, and the relationship between $V_{\max }$ and $w_{0}$ did not exhibit a bell-shaped profile. The optimum $w_{0}$ value at a constant $[\mathrm{E}]_{\mathrm{wp}}$ of $1.6 \mu \mathrm{g} \mathrm{ml}^{-1}$ was about 12.5 (Figure 5).

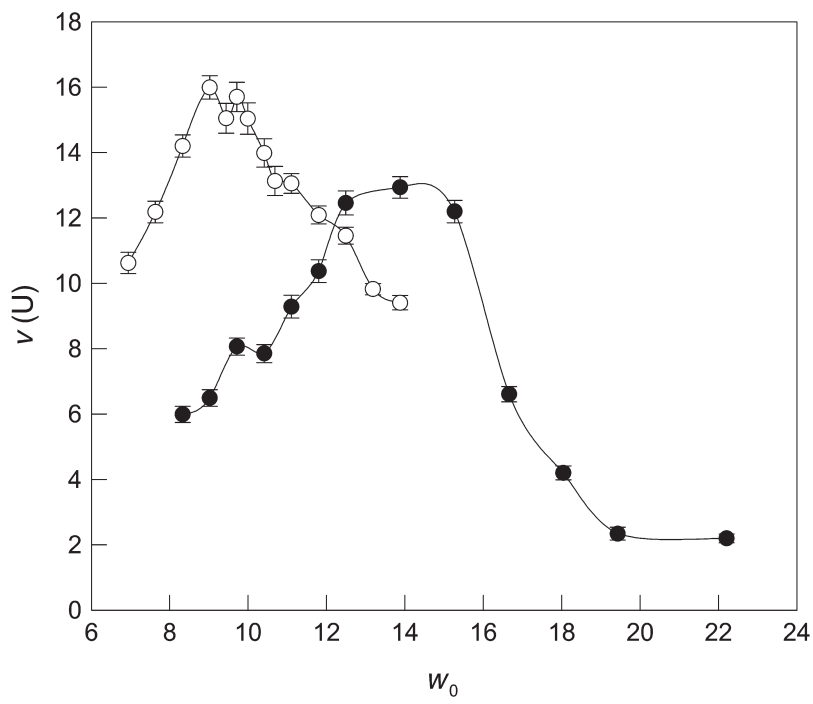

Figure 2. Effect of micellar water content $\left(w_{0}=\left[\mathrm{H}_{2} \mathrm{O}\right] /[\right.$ surfactant $\left.]\right)$ on activity of $p$ NPPase from $H$. salinarum in reverse micelles $(0.2 \mathrm{M}$ $\mathrm{CTAB}$ and $1 \mathrm{M}$ 1-butanol in cyclohexane) with $1 \mathrm{M} \mathrm{NaCl}(\bigcirc)$ or $0.075 \mathrm{M} \mathrm{NaCl}(\mathbf{)})$. The reaction was initiated by microinjection of substrate into reverse micelles containing enzyme. Reaction conditions: $[p N P P]=172 \mathrm{mM}$ in $100 \mathrm{mM}$ Tris- $\mathrm{HCl}$ buffer, $\mathrm{pH} 8.5$, containing $20 \mathrm{mM}$ 2-mercaptoethanol and $5 \mathrm{mM} \mathrm{MnCl}_{2}$; temperature = $40{ }^{\circ} \mathrm{C}$; protein concentration $=0.6 \mu \mathrm{g} \mathrm{ml}^{-1}$. 


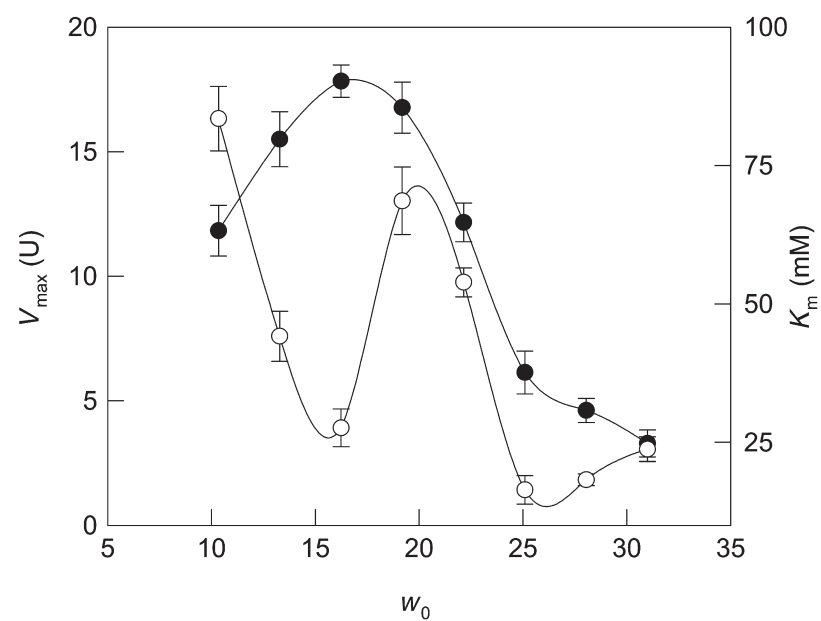

Figure 3. Effect of micellar water content $\left(w_{0}=\left[\mathrm{H}_{2} \mathrm{O}\right] /[\right.$ surfactant $\left.]\right)$ on the kinetic parameters of $p$ NPPase from $H$. salinarum in reverse micelles (0.2 M CTAB and $1 \mathrm{M}$ 1-butanol in cyclohexane): $V_{\max }(\bullet)$ and $K_{\mathrm{m}}(\bigcirc)$. The reaction was initiated by mixing reverse micelles containing $p$ NPPase with reverse micelles containing substrate ( $p$ NPP). The buffer in the water pool was $100 \mathrm{mM}$ Tris-HCl, pH 8.5, containing $100 \mathrm{mM} \mathrm{NaCl}, 20 \mathrm{mM}$ 2-mercaptoethanol and $5 \mathrm{mM} \mathrm{MnCl}_{2}$. Temperature of the reaction was $40{ }^{\circ} \mathrm{C}$. Enzyme concentration was $0.6 \mu \mathrm{g} \mathrm{ml} \mathrm{m}^{-1}$

\section{Discussion}

A previous study examining the activity of the halophilic enzyme $p$ NPPase in aqueous medium showed that the activity in the absence of salts was only about $15 \%$ of the maximum activity achieved in the presence of $\mathrm{NaCl}$ concentrations greater than 1.2 M (Bonet et al. 1991). In this study, the enzyme was

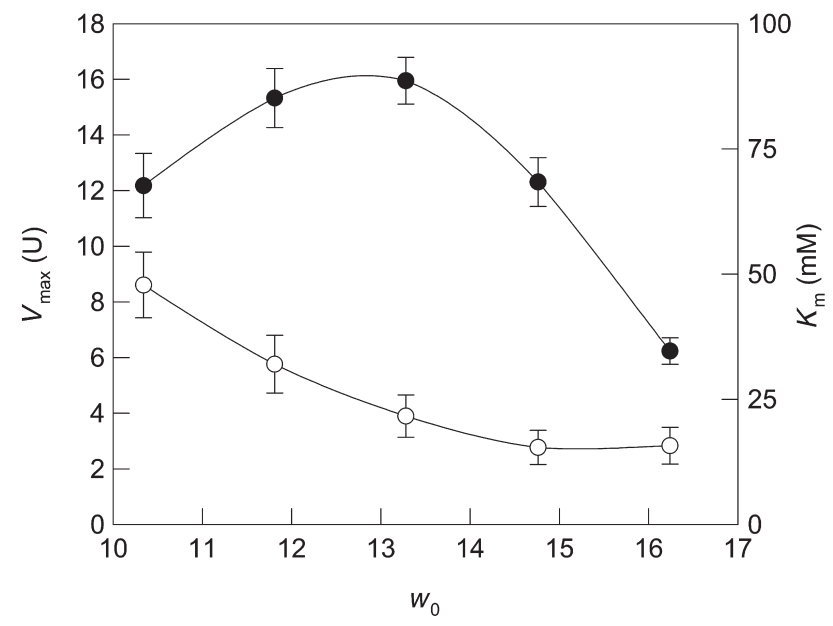

Figure 4. Effect of micellar water content $\left(w_{0}=\left[\mathrm{H}_{2} \mathrm{O}\right] /[\right.$ surfactant $\left.]\right)$ on the kinetic parameters of $p$ NPPase from $H$. salinarum in reverse micelles (0.2 M CTAB and $1 \mathrm{M}$ 1-butanol in cyclohexane): $V_{\max }(\bullet)$ and $K_{\mathrm{m}}(\bigcirc)$. The reaction was initiated by mixing reverse micelles containing enzyme with reverse micelles containing substrate. The buffer in the water pool was $100 \mathrm{mM}$ Tris- $\mathrm{HCl}, \mathrm{pH} 8.5$, containing $100 \mathrm{mM}$ $\mathrm{NaCl}, 20 \mathrm{mM}$ 2-mercaptoethanol and $2 \mathrm{mM} \mathrm{MnCl}$. Temperature of the reaction was $40^{\circ} \mathrm{C}$. Protein concentration was $0.6 \mu \mathrm{g} \mathrm{ml}^{-1}$.

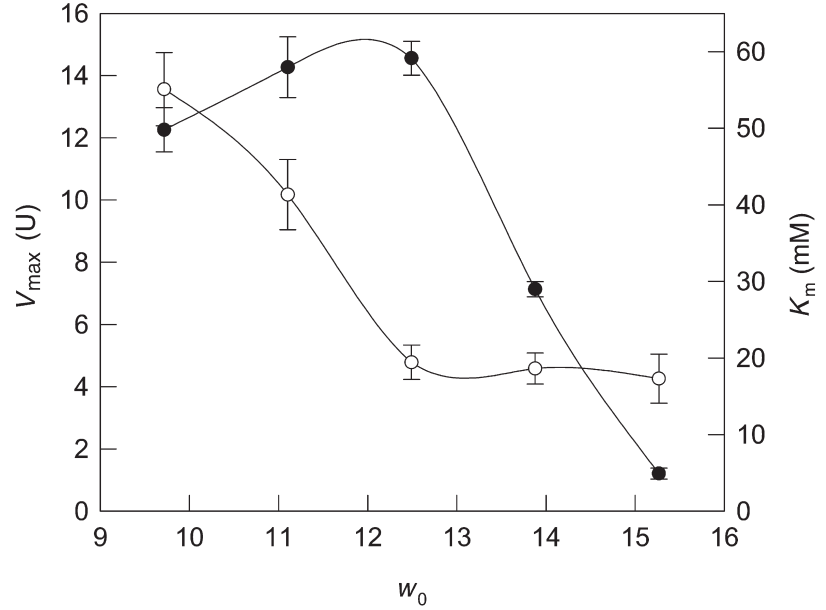

Figure 5. Effect of water content on the kinetic parameters of $p$ NPPase from $H$. salinarum $\left(V_{\max }\right)$ in reverse micelles (0.2 M CTAB and $1 \mathrm{M}$ 1-butanol in cyclohexane): $V_{\max }(\bigcirc)$ and $K_{\mathrm{m}}(\bigcirc)$. The enzyme concentration in the water pool $\left([\mathrm{E}]_{\mathrm{wp}}\right)$ was held constant at $1.6 \mu \mathrm{g} \mathrm{ml}^{-1}$. The reaction was initiated by mixing reverse micelles containing enzyme with reverse micelles containing substrate. The buffer in the water pool was $100 \mathrm{mM}$ Tris- $\mathrm{HCl}, \mathrm{pH} 8.5$, containing $100 \mathrm{mM} \mathrm{NaCl}, 20 \mathrm{mM}$ 2-mercaptoethanol and $2 \mathrm{mM} \mathrm{MnCl}_{2}$. Temperature of the reaction was $40^{\circ} \mathrm{C}$.

able to maintain its catalytic properties when encapsulated in reverse micelles in a medium containing a low salt concentration. The kinetic behavior and parameters were similar at both 0.85 and $0.048 \mathrm{M} \mathrm{NaCl}$ when the reaction was initiated by mixing reverse micelles containing enzyme with reverse micelles containing substrate (Figure 1). When the reaction was initiated by microinjection of substrate into reverse micelles containing enzyme (Marhuenda-Egea et al. 2000a), it followed Michaelis-Menten kinetics at high salt concentration $(0.85 \mathrm{M} \mathrm{NaCl})$, but not at low salt concentration $(0.048 \mathrm{M}$ $\mathrm{NaCl}$ ) (Marhuenda-Egea et al. 2001b).

After microinjection of substrate, the reverse micelles containing enzyme were momentarily destroyed, but reformed after a few seconds of vigorous vortexing. Destruction of the micellar system does not occur if reverse micelles containing enzyme are mixed with reverse micelles containing substrate. During reformation of the reverse micellar system following microinjection of substrate, different components of the system, i.e., enzyme, surfactant or organic solvent, may come into contact with each other (Khmelnitsky et al. 1993). These interactions may cause partial denaturation of the enzyme or may modify its catalytic properties (Khmelnitsky et al. 1993).

Our results indicate that it is possible to work with an extreme halophilic enzyme, like $p$ NPPase from $H$. salinarum, in organic solvents, and that the reaction follows MichaelisMenten kinetics when the reaction is initiated by mixing reverse micelles containing enzyme and reverse micelles containing substrate (Figure 1). The difference in enzymatic activity in the presence of high and low salt concentrations was only about $10 \%\left(V_{\max }=19.4 \pm 0.4 \mathrm{U}\right.$ at $0.85 \mathrm{M} \mathrm{NaCl}$ and $V_{\max }=17.5$ $\pm 1.0 \mathrm{U}$ at $0.048 \mathrm{M} \mathrm{NaCl}$, for mixing of reverse micelles). 
However, in aqueous medium, the difference was approximately $85 \%$ (Bonet et al. 1991), indicating that the reverse micellar system has a stabilizing effect on the halophilic enzyme (Marhuenda-Egea et al. 2001a).

The profile of $p$ NPPase activity as a function of $w_{0}$ exhibited the typical bell-shaped curve, and the optimum $w_{0}$ value varied depending on the $\mathrm{NaCl}$ concentration employed (Figure 2). The optimum $w_{0}$ value at $0.075 \mathrm{M} \mathrm{NaCl}(14)$ was higher than at $1 \mathrm{M} \mathrm{NaCl}\left(w_{0}=9\right)$. The difference between the maximum activity of $p$ NPPase in reverse micelles with $1 \mathrm{M} \mathrm{NaCl}$ and with $0.075 \mathrm{M} \mathrm{NaCl}$ was approximately $20 \%$ (Figure 2). A two-phase system in which a reverse micellar microemulsion is in equilibrium with a conjugate aqueous phase containing $\mathrm{NaCl}$ can be prepared with sodium bis(2-ethylhexyl)sulfosuccinate (AOT) (Fletcher and Parrot 1988). Under these conditions, the size of the reverse micelles can be varied systematically by altering the aqueous phase $\mathrm{NaCl}$ concentration (Fletcher and Parrot 1988). For the same $w_{0}$ value, if there is no aqueous phase in equilibrium with the reverse micellar phase, the system is monodispersed and the droplet size should be similar at 1 and $0.075 \mathrm{M} \mathrm{NaCl}$.

The difference in ionic strength between 1 and $0.075 \mathrm{M}$ $\mathrm{NaCl}$ can modify the structure of the water inside the reverse micelles as well as the structure of the reverse micelle itself. When the salt concentration increased, the stability of the reverse micellar system decreased and the range of $w_{0}$ values narrowed (Marhuenda-Egea et al. 2000a). Reverse micelles formulated with $\mathrm{CTAB}$ destabilized at $\mathrm{NaCl}$ concentrations above $1 \mathrm{M}$. In aqueous medium, the presence of salt causes restructuring of the hydrogen-bonded network of water molecules as salt ions become hydrated. The effect of high salt concentrations on the structure of water molecules may be critical to the stability of extreme halophilic enzymes (Madern et al. 2000). In reverse micelles, cationic surfactants such as $\mathrm{CTAB}$ can disrupt hydrogen bonds between water molecules in the same way that high salt concentrations do. Within the reverse micelle, two regions with different water structures may exist (Bru et al. 1995). One region consists of water structured around the polar heads of the surfactant, whereas the other region consists of free water in the center of the water pool within the micelle (Bru et al. 1995). At low $w_{0}$ values, all water is structured (i.e., arranged around the polar heads of surfactant molecules) and the stability of the enzyme increases (Marhuenda-Egea et al. 2001a). When $w_{0}$ is increased, the structure of the water in the reverse micelles changes and the activity of the encapsulated enzyme increases (Tuena de Gómez-Puyou and Gómez-Puyou 1998, Marhuenda-Egea et al. 2000b) until high $w_{0}$ values are reached, at which point the proportion of free water increases and enzyme stability and activity decrease (Bru et al. 1995). The increase in the relative amount of free water at $0.075 \mathrm{M} \mathrm{NaCl}$ may be the cause of the decrease in enzyme activity as $w_{0}$ increases (Figure 2). On the other hand, at $1 \mathrm{M} \mathrm{NaCl}$, the water is structured by the high salt concentration and this should result in an increase in or the maintenance of the enzyme activity as $w_{0}$ increases. However, the relationship between enzyme activity and $w_{0}$ at $1 \mathrm{M} \mathrm{NaCl}$ also has a bell-shaped profile, i.e., the enzyme activity de- creases at higher $w_{0}$ values (Figure 2). This decrease in enzyme activity at $1 \mathrm{M} \mathrm{NaCl}$ with increasing $w_{0}$ may be a result of the instability of the reverse micelles at higher $w_{0}$ values. When substrate was microinjected into reverse micelles at $1 \mathrm{M} \mathrm{NaCl}$, the ternary system required more vigorous vortexing (about 30 s) at higher $w_{0}$ values to reform the reverse micellar system. During this time, the possibility of contact between the enzyme and other components of the system (i.e., surfactant and organic solvent), which may modify the catalytic properties of the enzyme, increased.

To avoid possible denaturation of the enzyme by contact with the surfactant or the organic solvent, the reactions shown in Figures 3 and 4 were initiated by mixing reverse micelles containing enzyme with reverse micelles containing substrate. Bell-shaped curves of $V_{\max }$ as a function of $w_{0}$ were obtained at low salt concentration $(0.100 \mathrm{M} \mathrm{NaCl})$ with $2 \mathrm{mM} \mathrm{Mn}^{2+}$ (Figure 3) or $5 \mathrm{mM} \mathrm{Mn}^{2+}$ (Figure 4). The bell-shaped curves (i.e., the decrease in $V_{\max }$ at higher $w_{0}$ values) may be explained by the halophilic nature of the $p$ NPPase, because these bellshaped profiles were not observed at a higher salt concentration $(0.85 \mathrm{M} \mathrm{NaCl})$ when mixing of reverse micelles was used to initiate the reaction (Marhuenda-Egea et al. 2000b). In this experiment, $V_{\max }$ increased with water content until the limit of thermodynamic stability was reached (Marhuenda-Egea et al. $2000 b$ ).

It is known that halophilic enzymes such as $p$ NPPase from $H$. salinarum contain a higher proportion of acidic amino acid residues (the isoelectric point of $p$ NPPase was about 4) than their non-halophilic homologs (Lanyi 1974). Statistical analysis of 26 soluble proteins confirmed the acidic nature of the halophilic enzymes and showed that they contained a significantly lower Lys residue content, a greater proportion of small hydrophobic residues (Gly, Ala, Val) and a lower proportion of aliphatic residues (Madern et al. 1995). In addition, a high glutamate content in halophilic enzymes may be favorable, as glutamate has the greatest water binding capacity of all the amino acids, thus facilitating the maintenance of a hydration shell. In our experiments and in our discussion, we have considered the halophilic $p$ NPPase to be negatively charged.

$p$-Nitrophenylphosphate phosphatase exhibits behavior typical of halophilic enzymes, requiring high salt concentrations for maximal activity (Bonet et al. 1991). The activity in the absence of salts was about $15 \%$ of the maximum activity achieved with 1.6 M NaCl (Bonet et al. 1991). High cation concentrations within the cell may, in part, be required to shield the negative charges on the protein surface. High salt concentrations help maintain weak hydrophobic interactions (Lanyi 1974) and may, therefore, help preserve the structural stability of halophilic enzymes despite their low hydrophobic residue content. Accordingly, most enzymes of haloarchaea, like $p$ NPPase, denature when suspended in solutions containing salt concentrations less than 1 to $2 \mathrm{M}$ (Bonet et al. 1991, Eisenberg et al. 1992). A thermodynamic "solvation-stabilization hypothesis" has been formulated to explain the stabilization of halophilic proteins by salt in terms of protein-solvent interactions (Ebel et al. 1999). According to this model, the stability of the folded protein depends on a network of hy- 
drated ions associated with acidic residues at the protein surface.

The cationic polar heads of CTAB molecules can modify the aqueous microenvironment of the enzyme, and thus at low $w_{0}$ values, because of the small size of the reverse micelles, could play the same role as cations in the cytoplasm of halophilic archaea. $p$-Nitrophenylphosphate phosphatase was more stable in reverse micelles with CTAB than in aqueous medium (Marhuenda-Egea et al. 2001a), and this stabilizing effect of reverse micelles was improved at lower $w_{0}$, even at low salt concentration (Marhuenda-Egea et al. 2001a). As the $w_{0}$ value increases, the size of the micellar interior increases, and the enzyme encapsulated within the micelle is less likely to come into contact with the cationic heads of the surfactant molecules (Marhuenda-Egea et al. 2000b). According to the "solvation-stabilization hypothesis" (Ebel et al. 1999), at high $w_{0}$ values, the local environment of the enzyme is characterized by low salt concentration and more "free water," i.e., the conditions would be the same as those in aqueous medium at low salt concentration.

The relationships between $V_{\max }$ and $w_{0}$ exhibited similar bell-shaped profiles whether the enzyme concentration within the micelles $\left([\mathrm{E}]_{\mathrm{wp}}\right.$ ) was held constant (Figure 5) or decreased (i.e., the enzyme concentration within the system ([E $]_{\text {ov }}$ ) was held constant; Figures 2-4) as $w_{0}$ increased. Although it is reasonable to assume that the bell-shaped profiles (i.e., the decrease in $V_{\max }$ with increasing $w_{0}$ ) in Figures 2-4 are attributable to the decrease in enzyme concentration within the micelles, the results shown in Figure 5, where the enzyme concentration was held constant, strongly suggest that the bellshaped dependence of $V_{\max }$ on $w_{0}$ is instead a result of the physical structure of the reverse micelles and the halophilic nature of $p$ NPPase, as discussed above.

In conclusion, these results demonstrate the feasibility of performing studies with halophilic proteins at very low salt concentrations and of exploiting the tremendous synthetic potential of extreme halophilic enzymes for biocatalysis in low water or nonaqueous environments (Dordick et al. 1998). Furthermore, this system can be used to study the contributions of water, salts and metallic ions to the stability and catalytic properties of halophilic enzymes.

\section{Acknowledgments}

This work was supported by funds from the Comisión Interministerial de Ciencia y Tecnología (CICYT-BT 87-0033) and the European Commission's Generic Project "Biotechnology of Extremophiles" (Contract BIO-CT93-02734).

\section{References}

Boicelli, C.A., F. Conti, M. Giomini and A.M. Guiliani. 1982. The influence of phosphate buffers on the ${ }^{31} \mathrm{P}$ longitudinal relaxation time in inverted micelles. Spectrochim. Acta Part A Mol. Biomol. Spectrosc. 38A:299-300.

Bonet, M.L., F.I. Llorca and E. Cadenas. 1991. Purification and some properties of an atypical alkaline $p$-nitrophenylphosphate phosphatase activity from Halobacterium halobium. Int. J. Biochem. 23:1445-1451.
Bradford, M.M. 1976. A rapid and sensitive method for the quantitation of microgram quantities of protein utilizing the principle of protein-dye binding. Anal. Biochem. 72:248-254.

Bru, R., A. Sánchez-Ferrer and F. García-Carmona. 1989. A theoretical study on the expression of enzymatic activity in reversed micelles. Biochem. J. 259:355-361.

Bru, R., A. Sánchez-Ferrer and F. García-Carmona. 1995. Kinetics models in reversed micelles. Biochem. J. 310:721-739.

Carvalho, C.M.L. and J.M.S. Cabral. 2000. Reverse micelles as reaction media for lipase. Biochimie 82:1063-1085.

Dordick, J.S., Y.L. Khmelnitsky and M.V. Sergeeva. 1998. The evolution of biotransformation technologies. Curr. Opin. Microbiol. 1: 311-318.

Ebel, C., P. Faou, B. Franzetti, B. Kernel, D. Madern, M. Pascu, C. Pfister, S. Richard and G. Zaccai. 1999. Molecular interactions in extreme halophiles: the solvation-stabilization hypothesis for halophilic proteins. In Microbiology and Biogeochemistry of Hypersaline Environments. Ed. A. Oren. CRC Press, Boca Raton, pp 227-237.

Eisenberg, H., M. Maverech and G. Zaccai. 1992. Biochemical, structural, and molecular genetic aspects of halophilism. Adv. Prot. Chem. 43:1-62.

Faeder, J. and B.M. Ladanyi. 2000. Molecular dynamics simulations of the interior of aqueous reverse micelles. J. Phys. Chem. B 104:1033-1046.

Fletcher, P.D.I. and D. Parrot. 1988. The partitioning of proteins between water-in-oil microemulsions and conjugate aqueous phase. J. Chem. Soc. Faraday Trans. I 84:1131-1144.

Han, D., P. Walde and P.L. Luisi. 1990. Dependence of lipase activity on water content and enzyme concentration in reversed micelles. Biocatalysis 4:153-161.

Kabanov, A., A.V. Levashov, N.L. Klyachko, S.N. Namyotkin, A.V. Pshezhetsky and K. Martinek. 1988. Enzymes entrapped in reversed micelles of surfactants in organic solvents: A theorical treatment of the catalytic activity regulation. J. Theor. Biol. 133: 327-343.

Khmelnitsky, Y.L., R. Hilhorst, A.J.W.G. Visser and C. Veeger. 1993. Enzyme inactivation and protection during entrapment in reversed micelles. Eur. J. Biochem. 211:73-77.

Lanyi, J.K. 1974. Salt-dependent properties of proteins from extremely halophilic bacteria. Bacteriol. Rev. 38:272-290.

Luisi, P.L., M. Giomini, M.P. Pileni and B.H. Robinson. 1988. Reversed micelles as hosts for proteins and small molecules. Biochim. Biophys. Acta 947:209-246.

Madern, D., C. Ebel and G. Zaccai. 2000. Halophilic adaptation of enzymes. Extremophiles 4:91-98.

Madern, D., C. Pfister and G. Zaccai. 1995. A single acidic amino acid mutation enhances the halophilic behaviour of malate dehydrogenase from Haloarcula marismortui. Eur. J. Biochem. 230: 1088-1095.

Marhuenda-Egea, F.C., S. Piera-Velázquez, C. Cadenas and E. Cadenas. 2000a. Kinetic studies of an extremely halophilic enzyme entrapped in reversed micelles. Biocatal. Biotransform. 18:201-222.

Marhuenda-Egea, F.C., S. Piera-Velázquez, C. Cadenas and E. Cadenas. 2000b. Enzymatic activity of an extremely halophilic phosphatase from the Archaea Halobacterium salinarum in reversed micelles. J. Mol. Catal. B Enzym. 10:555-563.

Marhuenda-Egea, F.C., S. Piera-Velázquez, C. Cadenas and E. Cadenas. 2001a. Stability of an extreme halophilic alkaline phosphatase from Halobacterium salinarum in non-conventional medium. J. Biotechnol. 87:255-261. 
Marhuenda-Egea, F.C., S. Piera-Velázquez, C. Cadenas and E. Cadenas. 2001b. Kinetic regulation of an alkaline $p$-nitrophenylphosphate phosphatase from Halobacterium salinarum in low water system by $\mathrm{Mn}^{2+}$ and monovalent cations. FEMS Microbiol. Lett. 198:111-115.

Martinek, K., A. Levashov, N. Klyachko, Y. Khmelnitski and I. Berezin. 1986. Micellar enzymology. Eur. J. Biochem. 155:453-468.

Nicot, C., M. Vacher, M. Vincent, J. Gallay and M. Waks. 1985. Membrane proteins in reverse micelles: Myelin basic protein in a membrane-mimetic environment. Biochemistry 24:7024-7032.
Novaki, L.P. and O.A.J. El Seoud. 1998. A Fourier transform infrared study on the structure of water solubilized by reverse aggregates of sodium and magnesium bis(2-ethilhexyl)sulfosuccinates in organic solvents. J. Colloid Interface Sci. 202:391-398.

O'Connor, C.J. and P.M. Wiggins. 1988. Ordered water structure and enhanced reactivity. Biocatalysis 1:249-256.

Tuena de Gómez-Puyou, M. and A. Gómez-Puyou. 1998. Enzymes in low water systems. Crit. Rev. Biochem. 33:53-89.

Zaccai, G. and H. Eisenberg. 1990. Halophilic proteins and influence of solvent on protein stabilization. Trends Biochem. Sci. 15: 333-337. 

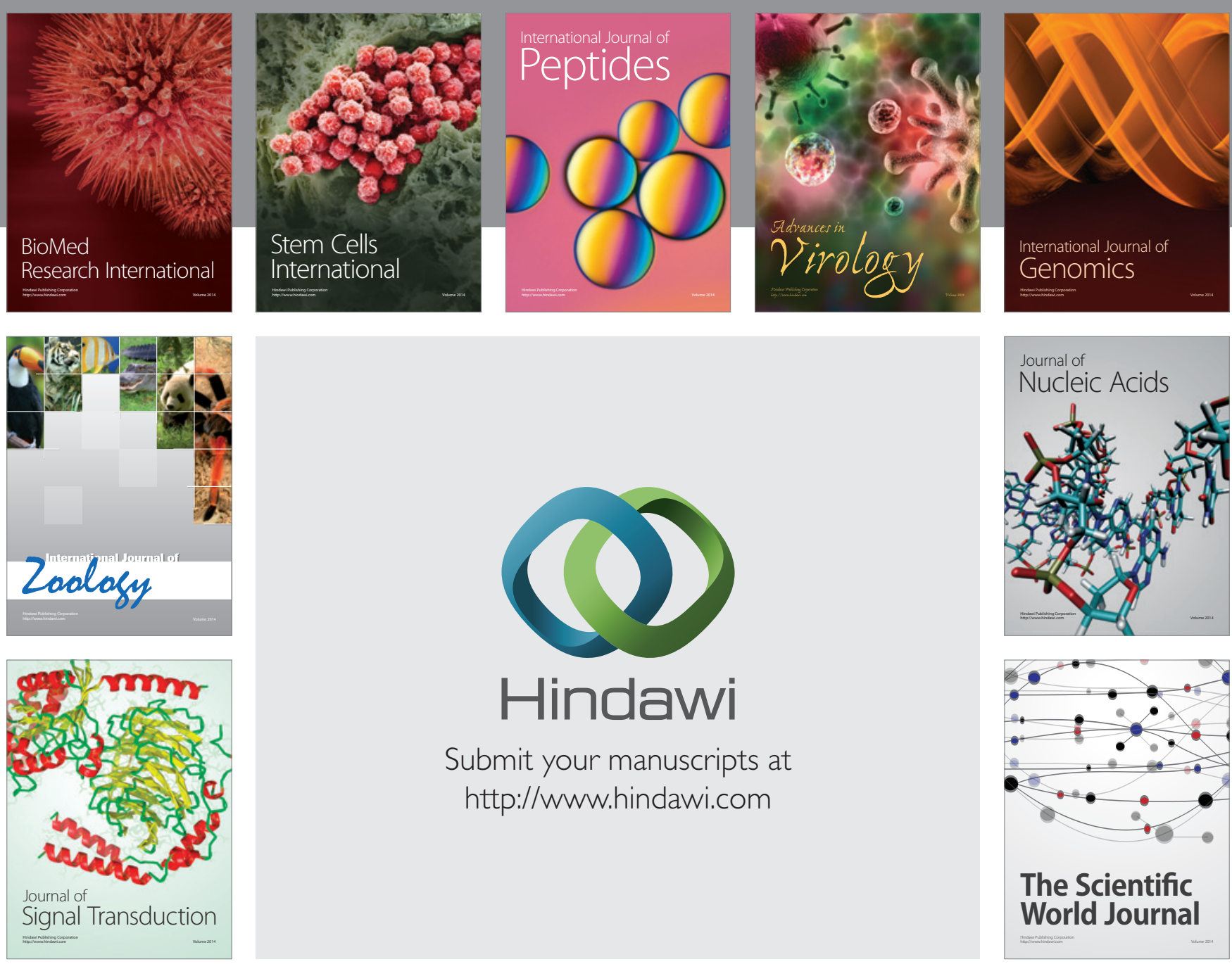

Submit your manuscripts at

http://www.hindawi.com
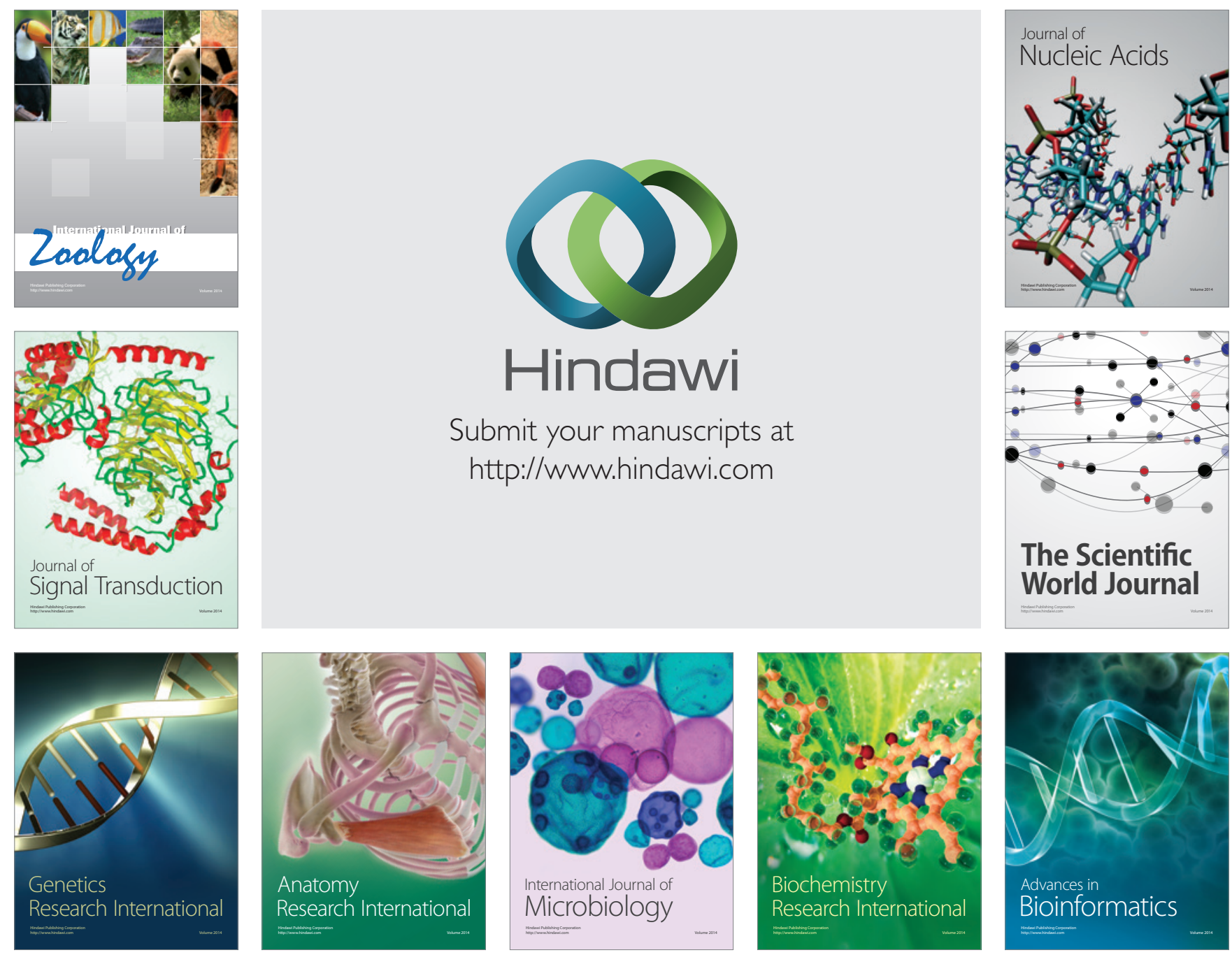

The Scientific World Journal
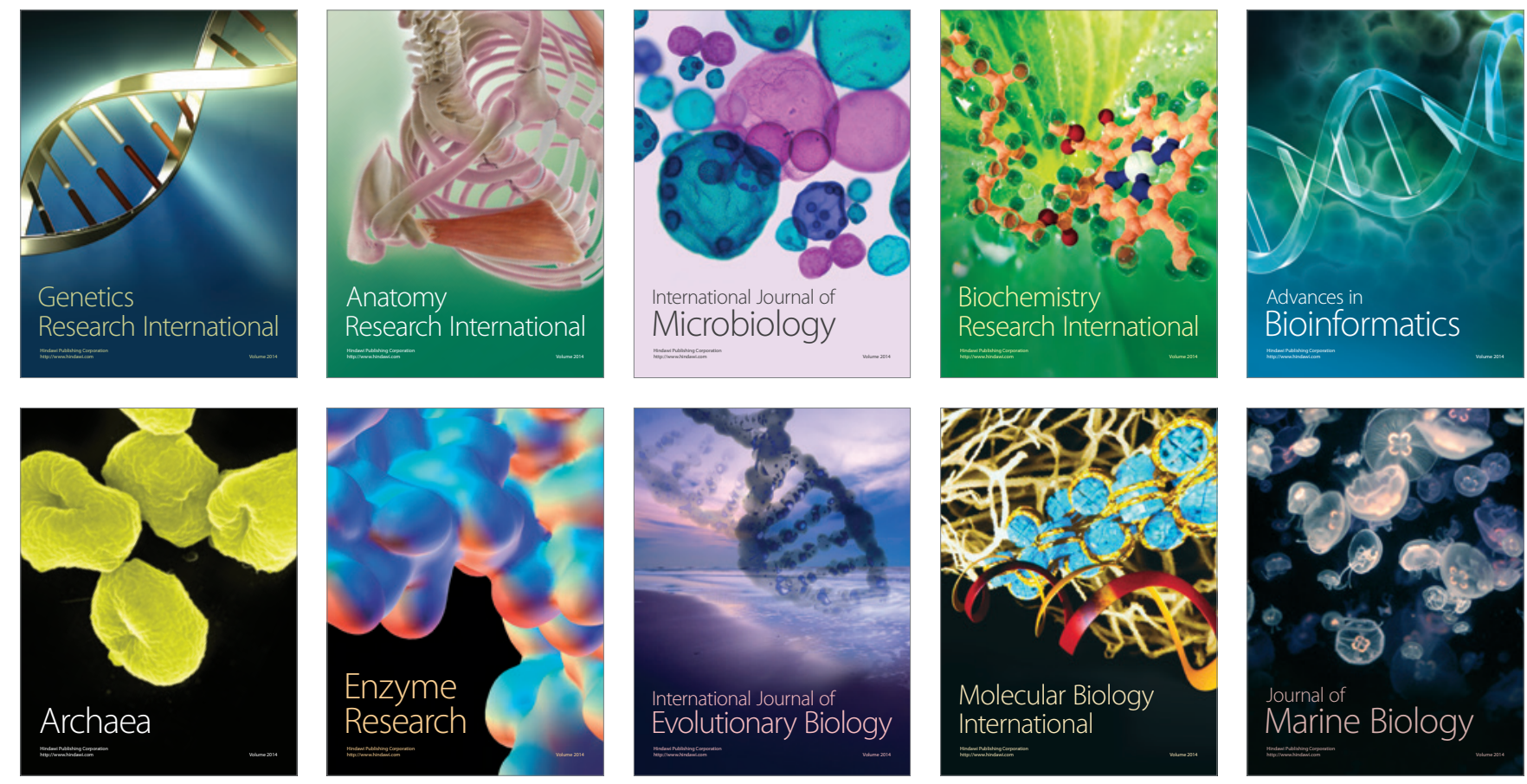